\title{
ANALYSIS OF BURULLUS WETLAND ECOSYSTEM USING DPSIR FRAMEWORK
}

\author{
El Bahrawy, A. N. ${ }^{(1)}$; Donia, Noha, S. ${ }^{(2)}$; Farouk, M. A. ${ }^{(3)}$ \\ and Sayed, Noha, $\mathrm{S}^{(3)}$
}

1) Irrigation and Hydraulic Department, Faculty of Engineering, Ain Shams Universit 2) Environmental Engineering Department, Institute of Environmental Studies and Research, Ain Shams University 3) Environmental Management Sector, Egyptian Environmental Affairs Agency

\begin{abstract}
Sustainable management of wetlands ecosystem become a serious crucial, especially with the rapid population growth and increase of anthropogenic activities, in addition to climate change threats. Several approaches have been introduced for ecosystem analysis and management since 1990s, where Driver - Pressure - State - Impact - Response (DPSIR) framework is one of the widely used approaches for assessing and managing environmental problems. This study applied DPSIR framework on Burullus wetland as a model of Egyptian Northern ecosystems, in order to analyze it from the perspective of its potential to deliver ecosystem services within current state of changes resulted from socio-economic drivers. Such changes have a direct or indirect impact on the wetland health and productivity, thus distress local communities relay on its services. Five main socio-economic drivers were analyzed and introduced through DPSIR framework. Number of actions and responses were recommended depending on DPSIR framework analysis. The results of this study will guide to prepare a management and restoration plan for Burullus wetland based on ecosystem approach.
\end{abstract}

Keywords: Driver, Pressure, State, Impact, Responses, DPSIR, Ecosystem Services, Burullus wetland, Restoration

Abbreviations:

IBA

Important Birds Area

DPSIR Driver - Pressure - State of Change - Impact - Response 


$\begin{array}{ll}\text { EEA } & \text { European Environment Agency } \\ \text { RS } & \text { Remote Sensing } \\ \text { SLR } & \text { Sea Level Rise } \\ \text { LU/LC } & \text { Land use/ Land cover }\end{array}$

\section{INTRODUCTION}

Wetlands are one of the most unique and productive worldwide ecosystems where terrestrial and aquatic habitats meet. They play a critical role in sustaining many natural cycles and supporting a wide range of biodiversity. Almost all of the world's water birds use wetlands as a feeding and breeding grounds. They also have vital recreational, historical, scientific and cultural values (UNEP, 2015).

Burullus wetland is the second-largest wetland in Egypt, located in the central part of the Northern section of the Nile Delta. It was declared a wetland nature reserve under the international Ramsar convention and a national protectorate in 1998 (Khedr \& Lovett-Doust, 2000). It offers a wide diversity of various habitats ranging from water fresh swamps, to salt marshes and mudflats. The shores and islets of the wetland comprise one of the most important reed beds in the Mediterranean region, where this type of habitat is becoming rare and threatened (Shaltout, 2017).

However, Northern wetlands in the Nile Delta of Egypt are recently under threats of anthropogenic stresses caused by the accelerated population growth (El-Asmar, Hereher, \& El-Kafrawy, 2012), coupled with unplanned developing activities that led to urbanization, posing serious implication on its current resources (Hegazy \& Kaloop, 2015). In addition to pollution from drainage water that discharge a huge amount of wastes enriched with 
agricultural fertilizers, industrial and sewage effluents. These conditions affected directly and/ or indirectly water quality of the wetland, causing eutrophication state (Okbah \& Hussein, 2005).

The increase of human pressures and consequent loss of wetlands need more efforts to conserve, where habitat conservation in terms of quantity and quality is a first priority (Khedr \& Lovett-Doust, 2000). Although assessing the link between human pressures and state-changes in marine and coastal ecosystems remain a challenge, there are several conceptual frameworks for describing these links (Patrício et al., 2016). Drivers - Pressures - State Impact - Responses (DPSIR) framework is one of the developed approaches that widely adopted to understand human causes of environmental degradation (Kristensen, 2004), DPSIR is a mean of structuring and analyzing information in decision-making across ecosystems (Patrício et al., 2016).

The objective of the present study is to analyze the state of Burullus wetland ecosystem within the recent pressures exerted from socio-economic drivers and to recommend a number of responses and actions needed to manage and restore the wetland to its natural condition when declared a protectorate in 1998.

\section{METHODOLOGY}

DPSIR framework was prepared based on understanding the interaction between socio-economic developments as a "Drivers" which exert or mitigate pressures on the environment. Such "Pressures" cause stresses on environmental status. "State" of environment change present its condition in terms of quantity and quality of resources. "Impacts" describe the effect of 
the changed environment and its consequences on human health and economy (Smeets \& Weterings, 1999). Accordingly, a number of "Responses" are recommended as a feedback loop to mitigate the environmental changes as shown in Figure (1).

State of change of Burullus wetland was assessed through an integrated overview of its provisional economic services, water quality status, land use change and their interactions. Set of indicators were addressed identifying the impact of exerted pressures on the wetland natural conditions. A number of responses were recommended to guide in preparation of integrated management and restoration plan based on ecosystem approach, as shown in Figure (2). The data was collected from different sources, including literature review, several field visits to selected villages of the five districts surrounding the wetland, direct interview of a number of relevant stakeholders. Besides, two questionnaires were prepared, fulfilled and analyzed. The first was questionnaire focusing on socio-economic and gender aspects, while the other focus on detailed economic valuation of the wetland's provisional ecosystem services.

\section{DESCRIPTION OF THE WETLAND ECOSYSTEM AND SERVICES}

The study area includes Burullus wetland and the five adminstrave districts surrounding it; Baltim, El-Hamoul, El-Riad, Sidisalem and Motobas. 1- Site Description: Burullus is one of the most vulnerable Egyptian wetlands along the Mediterranean coast. It is situated at the north central part of the Delta between $30^{\circ} 30^{\prime}$ and $31^{\prime} 10^{\prime} \mathrm{E}$ and latitudes $31^{\circ} 19^{\prime}$ and $31^{\prime} 36^{\prime} \mathrm{N}$. The wetland is located between the two Nile River branches: Damietta and 
Rosetta, in Kafr El Sheikh Governorate as shown in (Figure 3) (Attia, 1992). It is a shallow brackish water wetland with an average depth of $115 \mathrm{~cm}$. The wetland receives most of its water at its southern margins through agricultural drains. Besides, Brimbal Canal at the western part of the wetland and Mediterranean sea through a small opening called Boughaz EI-Burullus (Samaan et al., 1989). The wetland is rich of a variety of rare plants, animals and aquatic life as well as its special geographical nature used by migratory birds (Abayazid \& Al-Shinnawy, 2012).

2- Current Ecosystem Services: Burullus wetland offers several provisional, regulating, recreational ecosystem services. From analyzed questionnaires, it was clear that fishery and agriculture activities are considered the most important activities for local communities. The other activities include: reed harvesting, grazing, bird hunting, gathering economic plants and salt extraction with only a small minority working in fishery complementary industries e.g. boats industry. Economic activities in each district depend mainly on the available ecosystem services as shown in Table (1).

Table(1): Main activities in main districts around Burullus wetland

\begin{tabular}{|c|c|c|c|c|c|c|c||}
\hline District & Fishing & $\begin{array}{c}\text { Fishing } \\
\text { Industry }\end{array}$ & $\begin{array}{c}\text { Fish } \\
\text { Farming }\end{array}$ & Agriculture & Grazing & $\begin{array}{c}\text { Salt } \\
\text { Extraction }\end{array}$ & $\begin{array}{c}\text { Reed } \\
\text { Harvesting }\end{array}$ \\
\hline \hline Burullus & $\sqrt{ }$ & $\sqrt{ }$ & & $\sqrt{ }$ & $\sqrt{ }$ & $\sqrt{ }$ & $\sqrt{ }$ \\
\hline Sidisalem & $\sqrt{ }$ & $\sqrt{ }$ & & $\sqrt{ }$ & $\sqrt{ }$ & & \\
\hline El Hamoul & $\sqrt{ }$ & & $\sqrt{ }$ & & & & \\
\hline El Reyad & $\sqrt{ }$ & & & $\sqrt{ }$ & $\sqrt{ }$ & & \\
\hline Motobas & $\sqrt{ }$ & $\sqrt{ }$ & $\sqrt{ }$ & $\sqrt{ }$ & $\sqrt{ }$ & & \\
\hline
\end{tabular}


J. Environ. Sci.

Institute of Environmental Studies and Research - Ain Shams University

\section{RESULTS AND DISCUSSIONS}

The main components of DPSIR framework can be analyzed as following

1) Socio-Economic Drivers: The wetland ecosystem is affected by several socio-economic drivers resulting from rapid population growth and urbanization expansion which recently stresses its economic resources (Farag, 2011). The lowers lands at the southern boundary of the wetland have been extensively utilized by local communities for agriculture purposes; some of these low- level areas had been converted into fish farms due to its profitability (Asmar et al., 2013). Besides, the accelerated impact of sea level rise (SLR), with the subsidence of the Delta itself which makes the region one of the most vulnerable areas in the world (Zingstra, 2013). Most of these hazards are human-induced, except Delta subsidence and SLR that belong to the natural hazards (Asmar et al., 2012).

2) Main Environmental Pressures: The main pressures exerted from the above discussed drivers can summarized as follows:

A- Increase Of Drainage Discharge: Population growth, expansion of agricultural and industrial activities around the wetland led to huge amount of daily bypassing of untreated or partially treated sewage, industrial and uncontrolled agricultural waste water through water fresh drainage channels discharging into the wetland. Most of agricultural drainage water of middle Nile Delta is discharged in the wetland, where its southern side receives drainage water from agricultural drains $(11,9,8,7$, Nasser and 
El-Gharbia) as shown in Figure (4). The total drainage discharged into the wetland is 3904 million m3/year (Zeiny \& Kafrawy, 2017).

B- Climate Change Threats: Burullus wetland is highly vulnerable to climate change threats, due to temperature increases and sea level rise (SLR) threats. Possibilities of the wetland to mitigate SLR have decreased as a result of increasing discharged water into the wetland, causing a higher water level. Although sand dunes along the northern part naturally protect low lying area from SLR and salt intrusion of agriculture lands around the wetland, they are heavily threatened by erosion from anthropogenic activities (Asmar et al., 2012).

C- Unsustainable Fishing: Fish farming become a widespread activity along the southern shores of Burullus wetland since 1984 and recently increased along the northern shore, due to its higher profitability than agriculture (Figure 5). Part of that profitability is achieved by stocking of fry caught illegally at the inlet (El-Shinnawy, 2002). Overfishing of fry from the wetland has a substantial negative impact on fish stocks available for the fishermen and local markets. Rare species of amphibians and plants have been disappeared due to the creation of fish farm ponds (Zingstra, 2013).

3) State Change And Impact : Some indicators were proposed for assessing the changes in the wetland conditions and their impact on its health.

A- Land Use/ Land Cover Change From 1998 To 2015: Changes in land use/land cover (LU/LC) around the wetland, unwise urban development and construction of international high way that cuts through the northern sand bar, negatively affected its ecosystem. These changes impact socio- 
economic, biological, climatic and hydrological systems. A recent study compared LU/LC change of Burullus wetland from 1998 to 2015 using RS technique, clarified that the wetland is subjected to reduction in its area and sand bar by $22.8 \%, 8.5 \%$ respectively with increase in floating vegetation and surrounded agriculture land by $17.9 \%, 9.7 \%$ respectively (Hossena \& Negm, 2016), as shown in Figure (6).

B- Water Quality: Burullus wetland is one of the vulnerable ecosystems that suffers from dense blue green algae caused mainly by expansion of fish farming, agriculture activities, increasing fertilizers and pesticides concentration. Besides, the sediment pollution that contribute to water pollution of the wetland (Ali, 2011). The levels of pollution was classified into high $(15 \%)$ in the south, south western part and along the wetland shore lines which are most affected areas by human activities. Moderate $(73 \%)$ in the center of the wetland, where the anthropogenic activities decrease and typically the pollution is diluted and low (12\%) in the extreme north and in the core of the wetland (Zeiny \& Kafrawy, 2017).

C- Fish Quality And Quantity: Although annual fish statistics stated that total fish production of the wetland has reached 65,066 ton in 2015 (GAFRD, 2015), recently the amount of freshwater species have increased in comparison with marine species (more profitable) due to the decrease of sea water entering the wetland and increase of fresh water discharging from agriculture drainage as shown in Figure (7).

4) Stakeholder's Responsibilities: Identifying stakeholder's importance is an essential step for ensuring integrated management and preventing 
responsibilities overlap. Four categories were fulfilled according to Burullus wetland status. However, category IV is not effective in the wetland management as shown in Tables 2 and 3.

Table(2): Stakeholders Categorization (IUCN, 2014)

\begin{tabular}{|c|c|}
\hline $\begin{array}{c}\text { Category I: High importance, Low } \\
\text { influences }\end{array}$ & $\begin{array}{c}\text { Category II: High importance, High } \\
\text { influence }\end{array}$ \\
\hline $\begin{array}{c}\text { Category IV: Low importance, Low } \\
\text { influence }\end{array}$ & $\begin{array}{c}\text { Category III: Low importance, High } \\
\text { influence }\end{array}$ \\
\hline
\end{tabular}

Table(3): Stakeholders of Burullus wetland Identification

\begin{tabular}{|c|c|c|}
\hline Category I & Category II & Category III \\
\hline Primary stakeholders & Key stakeholders & Secondary stakeholders \\
\hline $\begin{array}{l}\text { Depend directly on } \\
\text { natural resources }\end{array}$ & $\begin{array}{l}\text { Significantly influence } \\
\text { any chosen intervention } \\
\text { in the environment }\end{array}$ & $\begin{array}{l}\text { Do not depend directly on the } \\
\text { natural resources/ have a major } \\
\text { interest in the way wetland is } \\
\text { managed }\end{array}$ \\
\hline $\begin{array}{l}\text { Fishermen } \\
\text { Aquaculture farmers } \\
\text { Agriculture farmers } \\
\text { Bird hunters }\end{array}$ & $\begin{array}{l}\text { Governorate } \\
\text { Ministry of Water } \\
\text { Resources } \\
\text { Ministry of Housing } \\
\text { Ministry of Defense } \\
\text { Ministry of Health } \\
\text { EEAA } \\
\text { Ministry of Agriculture } \\
\text { Ministry of Interior }\end{array}$ & $\begin{array}{l}\text { NGOs } \\
\text { Fishermen associations } \\
\text { Fishermen Chief } \\
\text { Universities and Research } \\
\text { institutions } \\
\text { Religious groups } \\
\text { Agriculture associations }\end{array}$ \\
\hline
\end{tabular}

\section{DPSIR ANALYSIS}

DPSIR framework was analyzed using a chain of causal links according to the main anthropogenic drivers discussed above; agricultural/industrial growth, expansion of fish farms, population growth and stakeholder's interest, while climate change is considered one of the natural drivers.

Pressures exerted on the wetland ecosystem and community's economy affected by its degradation were identified. State of change was analyzed in the prospective of quality and quantity that impact the ecosystem functions 
and human health. Required responses to mitigate the exerted pressures were recommended as short term management and restoration plan and long term strategies needed to improve the wetland status (Figure 8).

The next section shows DPSIR framework analysis for each proposed driver, results and recommendations through numbers of political responses that are needed to restore the wetland ecosystem.

\begin{tabular}{|c|c|}
\hline $\begin{array}{c}\text { Driver 1 } \\
\text { Agricultural / Ind ustrial Growth }\end{array}$ & $\begin{array}{l}\text { Pressure } 1 \\
\text { Quantity of waste water discharged into the } \\
\text { wetland: } \\
\text { - Agricultural: loaded with pesticides and } \\
\text { chemicals. } \\
\text { - Sewage: loaded with nutrients } \\
\text { - Industrial: loaded with chemicals and } \\
\text { heavy metals. } \\
\text { Increase sedimentation rate }\end{array}$ \\
\hline $\begin{array}{l}\text { Response } 1 \\
\text { - Develop a sewage network for } \\
\text { unserved villages. } \\
\text { - Implement new treatment plants and } \\
\text { enhance the current efficiency. } \\
\text { - Control industrial discharge } \\
\text { - Regular dred ging of wetland Bottom } \\
\text { and inlet. } \\
\text { - Sustainable cutting of reed and support } \\
\text { their industries. } \\
\text { - Raise farmer's awareness to decrease } \\
\text { pesticide and chemicals amount. } \\
\text { - Implement a simulation model and } \\
\text { propose solutions for its restoration. }\end{array}$ & $\begin{array}{l}\text { Quality: } \\
\text { - Degradation of water quality especially } \\
\text { near drains outlet. } \\
\text { - Increase nutrients level causing } \\
\text { eutrophication state. } \\
\text { - Increase floating vegetation } \\
\text { - Affect quality of fishery production. } \\
\text { Quantity: } \\
\text { - Water unbalance (increase of discharged } \\
\text { water from drainage). } \\
\text { - Decrease the amount of sea water entering } \\
\text { the wetland. }\end{array}$ \\
\hline $\begin{array}{l}\text { - Decrease the fish quality affect its pri } \\
\text { - Disappearance of some marine fish } \\
\text { - Vegetation increase affect water circ } \\
\text { - Increase of reeds causing an increase } \\
\text { - Health problems caused by pollution }\end{array}$ & $\begin{array}{l}\text { n and the free fishing areas. } \\
\text { e bottom level, affect water circulation. } \\
\text { ce man-power. }\end{array}$ \\
\hline
\end{tabular}




\begin{tabular}{|c|c|}
\hline $\begin{array}{c}\text { Driver 2 } \\
\text { Exponential Development of Fish } \\
\text { Farms }\end{array}$ & $\begin{array}{l}\text { Pressure } 2 \\
\text { Encouragement of illegal fry fishing. } \\
\text { - Discharged fish farms waste water in the } \\
\text { wetland rich with nutrients. } \\
\text { - Rapid increase of fish farm areas around } \\
\text { the wetland. }\end{array}$ \\
\hline $\begin{array}{l}\text { Response } 2 \\
\text { EnforceEIA studies for approval of } \\
\text { new aquaculture projects to regulate } \\
\text { locations, area and effluent } \\
\text { Encourage aquaculture best practices } \\
\text { and sustainable intensification. } \\
\text { Regular inspection of existing fish } \\
\text { farms status. } \\
\text { Law enforcement for banned fry } \\
\text { fishing. } \\
\text { Raise fishermen awareness to prevent } \\
\text { illegal practices. } \\
\text { Control the nutrients feeders. } \\
\text { Implement land use plan for } \\
\text { controlling activities in and around the } \\
\text { wetland }\end{array}$ & $\begin{array}{l}\text { Quality: } \\
\text { - Increase nutrients in the wetland from fish } \\
\text { farm discharge causing eutrophication } \\
\text { state. } \\
\text { - Affecting ecosystem service and } \\
\text { biodiversity. } \\
\text { Quantity: } \\
\text { - Reduction of wetland areas for fish } \\
\text { farming. } \\
\text { - Conversion of uncultivated agricultural } \\
\text { land into fish farms (more profitable). }\end{array}$ \\
\hline $\begin{array}{l}\text { Reduction of fish stock in the wetland. } \\
\text { Shrinkage of the wetland area affect th } \\
\text { Changes in the planned land use. } \\
\text { Increases the number of motored boats. } \\
\text { Decreases the possibility to harvest me }\end{array}$ & $\begin{array}{l}\text { pact } 2 \\
\text { free fishing. } \\
\text { ical plants which can provide an important }\end{array}$ \\
\hline
\end{tabular}


J. Environ. Sci.

Institute of Environmental Studies and Research - Ain Shams University

\begin{tabular}{|c|c|}
\hline $\begin{array}{c}\text { Driver } 3 \\
\text { Population Growth }\end{array}$ & $\begin{array}{l}\text { Pressure } 3 \\
\text { Over exploitation Ecosy stem services. } \\
\text { - Increase of illegal practices: overfishing, } \\
\text { illegal fishing and bird hunting. } \\
\text { - Food and water scarcity. } \\
\text { - Overstress local labor markets. } \\
\text { - Daily bypassing of untreated or partially } \\
\text { treated sewage. } \\
\text { - Garbage disposal. }\end{array}$ \\
\hline $\begin{array}{l}\text { Response } 3 \\
\text { - Develop sewage services and increase } \\
\text { the efficiency of current networks } \\
\text { - Support investments of small and very } \\
\text { small projects for local communities } \\
\text { around the wetland } \\
\text { - Empower women involvement } \\
\text { - Development of economic forward } \\
\text { linkages, i.e. linking agriculture and } \\
\text { fish production with processing } \\
\text { industries } \\
\text { - Public participation. Community Based } \\
\text { organization. } \\
\text { - Encourage eco-tourism }\end{array}$ & $\begin{array}{l}\text { Quality: } \\
\text { - Increase of Poverty level. } \\
\text { - Deterioration of water quality. } \\
\text { Quantity: } \\
\text { - Increase urbanization. } \\
\text { - Increase of wastewater quantity } \\
\text { discharged in the wetland through } \\
\text { drainage. } \\
\text { - Increase of garbage }\end{array}$ \\
\hline $\begin{array}{l}\text { Im } \\
\text { - Unsustainable utilization of ecosystem s } \\
\text { - Further subdivide the northern part of th } \\
\text { - Lack of employment and social services }\end{array}$ & $\begin{array}{l}\text { pact } 3 \\
\text { ervices in the wetland. } \\
\text { and and water imbalance. } \\
\text { e wetland. } \\
\text { ligration. }\end{array}$ \\
\hline
\end{tabular}




Driv er 4
Climate Change


J. Environ. Sci.

Institute of Environmental Studies and Research - Ain Shams University

\begin{tabular}{|c|c|}
\hline $\begin{array}{c}\text { Driv er 5 } \\
\text { Stakeholder's Interest }\end{array}$ & $\begin{array}{l}\text { Pressure 5 } \\
\text { - Multi-stakeholders. } \\
\text { - Overlapping of duties. } \\
\text { - Conflict between stakeholder's interests }\end{array}$ \\
\hline $\begin{array}{l}\text { Response } \mathbf{5} \\
\text { - Developing an integrated institutional } \\
\text { structure. } \\
\text { - Designation of technical committee for } \\
\text { biodiversity, land use, economic } \\
\text { resources and water quality. } \\
\text { - Comprehensivereview of current } \\
\text { institutional structures and related } \\
\text { policies in charge of Wetland Burullus. } \\
\text { - Enhancing science and policy } \\
\text { interface. } \\
\text { - Raise stakeholder awareness. } \\
\text { - Improve data sharing network. } \\
\text { - Implement a sustainable management }\end{array}$ & $\begin{array}{l}\text { Quality: State } \mathbf{5} \\
\text { - Degree of coordination. } \\
\text { - Clear identifications of responsibilities } \\
\text { key stakeholders. } \\
\text { Quantity: } \\
\text { - Number of responsible authorities. } \\
\text { - Number of relevant laws and legislations. } \\
\text { - Duplication of efforts. }\end{array}$ \\
\hline $\begin{array}{l}\text { - The lack of implementation of agreeme } \\
\text { continuously allowing illegal activities } \\
\text { - Weak law enforcement is misused for } f \\
\text { illegal urbanization, and several other } p \\
\text { - Lack of implementation of penalties for } \\
\text { - Lack of co ordination and information s } \\
\text { - Unclear responsibilities and lack of inte }\end{array}$ & $\begin{array}{l}\text { pact } 5 \\
\text { its and allocation of responsibilities is } \\
\text { o remain without consequences. } \\
\text { rther construction of aquaculture ponds, } \\
\text { ejudicial land conversions. } \\
\text { violation of existing laws. } \\
\text { aring. } \\
\text { rrated decisions. }\end{array}$ \\
\hline
\end{tabular}




\section{Dpsir Framework Clarifies The Following:}

- Main drivers affecting the wetland ecosystem services are agricultural and industrial growth, population growth, climate change, exponential development of fish farms and Stakeholders interests.

- The wetland receives drainage water that carry accumulated wastewater from agricultural activities loaded with pesticides and chemicals, industrial loaded with chemicals and heavy metals and sewage loaded with nutrients, affecting water quality and lead to eutrophication conditions in some parts of the wetland.

- The increase discharge of drainage water affects the amount of sea water entering the wetland through the inlet. Thus, affecting the water quality and sediment level in the wetland.

- Exponential development of fish farms change the land use, encourage illegal fry fishing and increase nutrient level in the wetland due to discharging of their waste water into the wetland.

- Area reduction is mainly attributed to the reclamation and drying processes of the fish ponds mainly in the South and East parts of Burullus region.

- Sea level rise, salt water intrusion and temperature increase resulting from climate change threats the wetland ecosystem and habitats.

- Multi-stakeholders, overlapping of duties and conflict between stakeholder's interests affect the management procedures. 


\section{Dpsir Framework Recommended The Following:}

- Implementing management and restoration plan to reduce current pressures and maintain future opportunities, e.g. collection and marketing of reeds.

- Enhancing cooperation between key stakeholders responsible for management of Burullus wetland and involving both primary and secondary stakeholders in decision making.

- Clarifying responsibilities between relevant stakeholders and building an interactive data sharing network between them.

- Encouraging private sector for more investments of small and minors industries to increase the local communities' income and best use of its ecosystem services.

- Supporting the touristic potential around the wetland for enhancing the population livelihood.

- Raising awareness of beneficiaries around the wetland that directly affect the wetland ecosystem.

- Enhancing social problems of local communities related to pension, health insurance and sewage services.

- Regular dredging of the wetland area and inlet to ensure the water circulation in the wetland.

- Adequate treatment for agriculture and municipal wastes before being discharged into the wetland.

- Preparing vulnerability zoning map and identifying hotspot areas. 


\section{FIGURES}

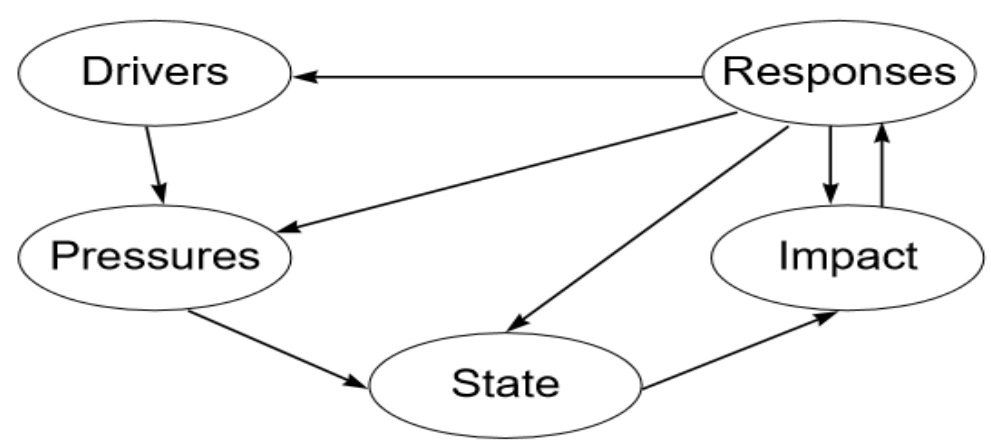

Figure(1): DPSIR framework chain (Smeets \& Weterings, 1999)

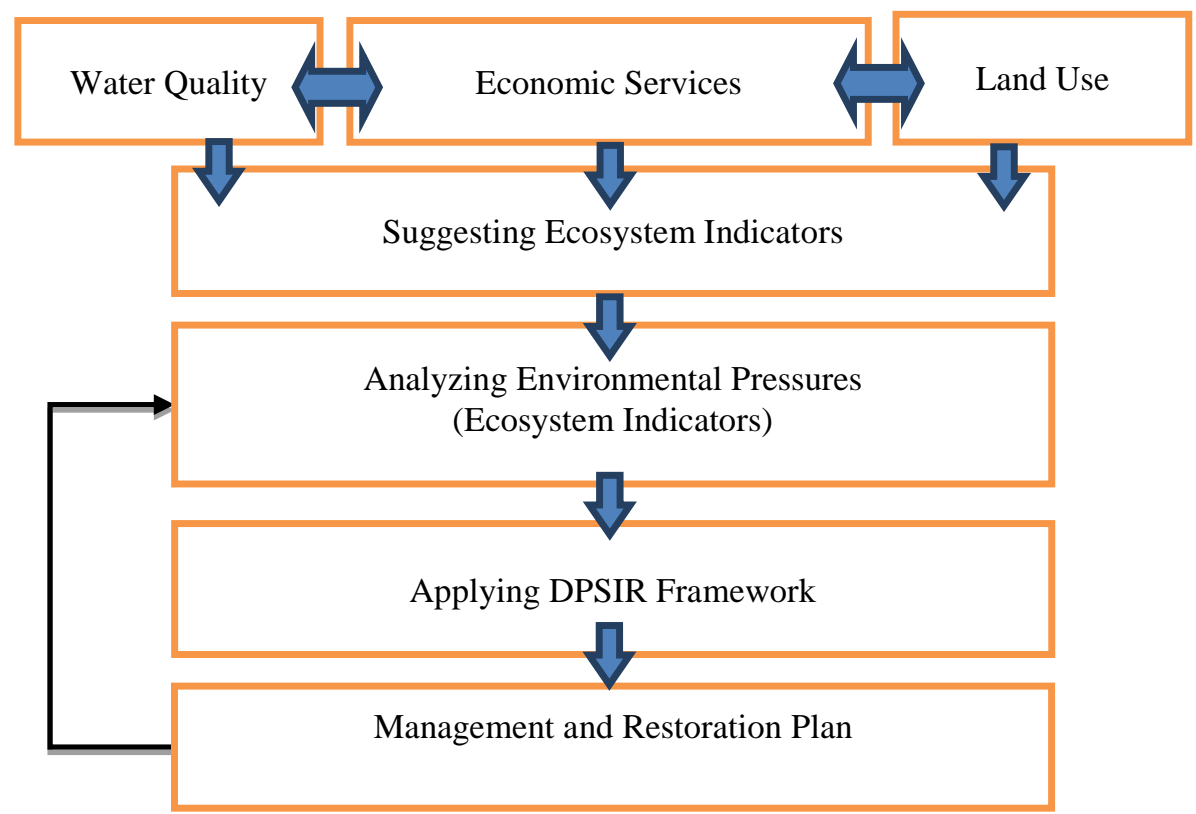

Figure(2): Proposed steps for assessing of Burullus wetland Ecosystem 


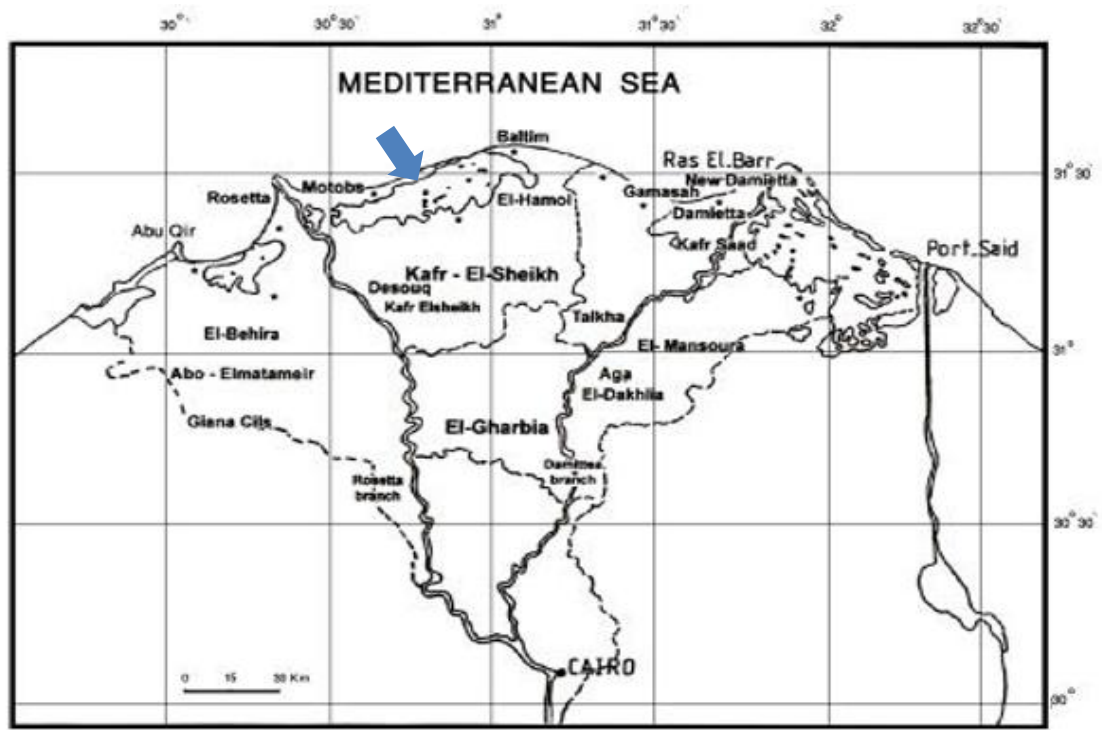

Figure(3): Burullus wetland location in the Nile Delta (Mashaly et al., 2008)

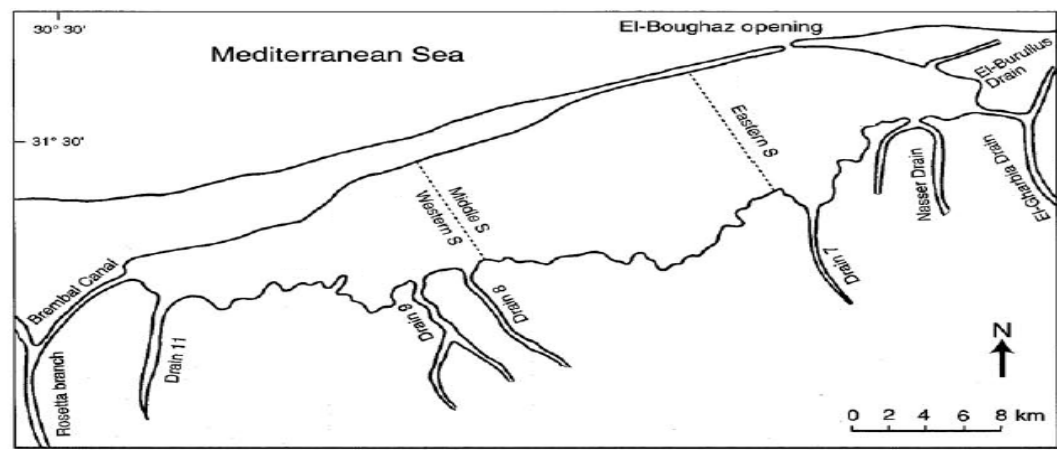

Figure(4): Drains discharged into Burullus wetland (El-Shinnawy I. A., 2003) 
El Bahrawy, et al.

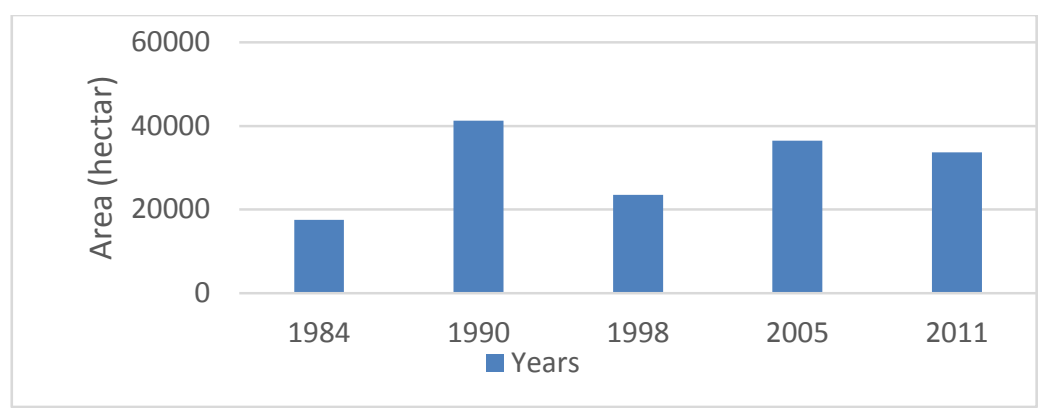

Figure(5): Expansion of fish farms around Burullus wetland (Zingstra, 2013)

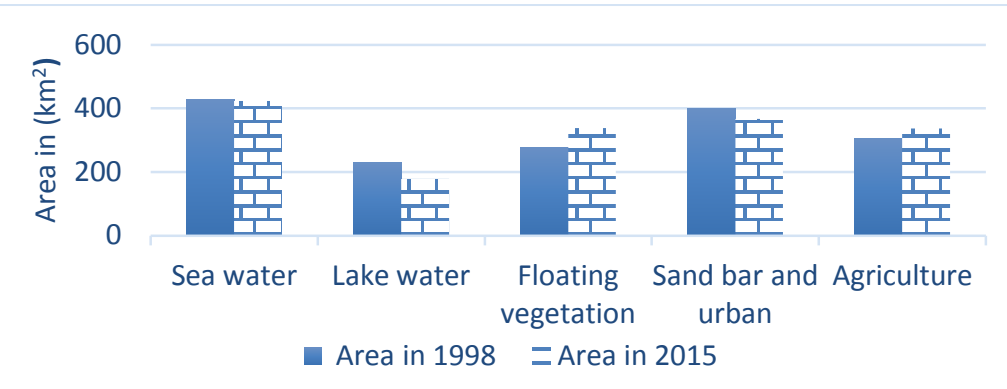

Figure(6): Change of LU/LC from 1998 to 2015 (Hossena \& Negm, 2016)
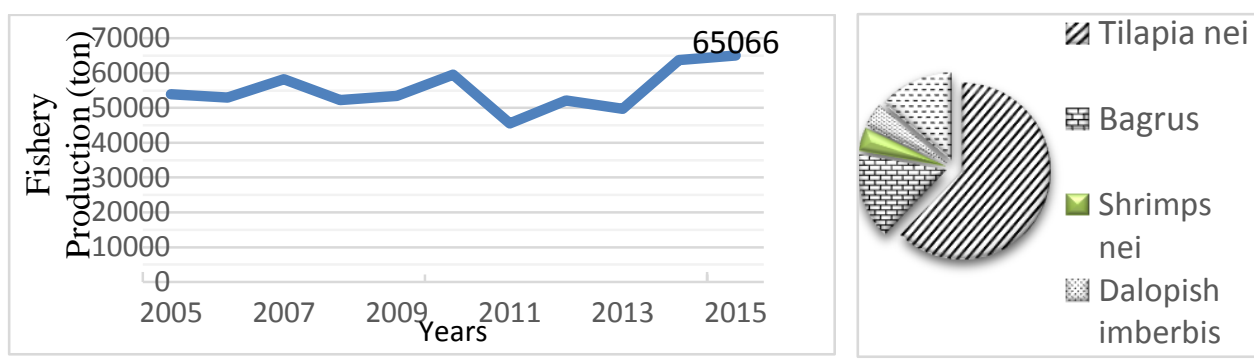

Figure(7): Annual trend of fish production (ton) - Percentage of fish type 
J. Environ. Sci.

Institute of Environmental Studies and Research - Ain Shams University

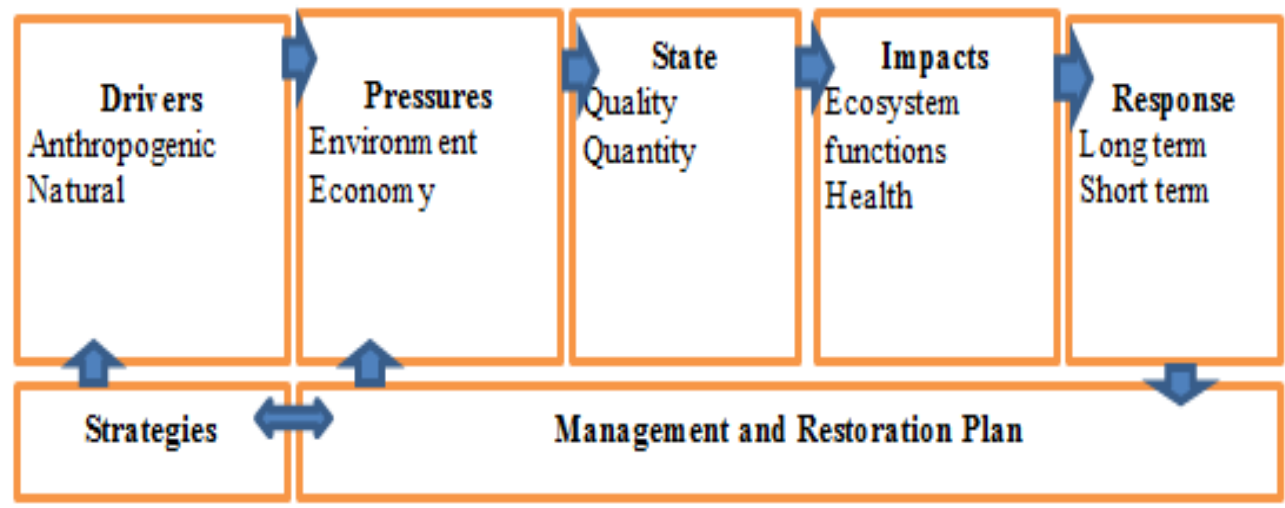

Figure(8): DPSIR Framework Analysis Chain

\section{REFERENCES}

Abayazid, H., and Al-Shinnawy, I. (2012). Coastal Lake Sustainability: Threats And Opportunities With Climate Change. IOSR Journal of Mechanical and Civil Engineering, Volume 1, 33-41.

Ali, E. M. (2011). Impact of drain water on Water Quality and Eutrophication Status of Lake Burullus, Egypt, a Southern Mediterranean lagoon. African Journal of Aquatic Science, Volume 36, 37-41.

Asmar, H. M., Hereher, M. E., and El-Kafrawy, S. B. (2012). Threats Facing Lagoons Along the North Coast of the Nile Delta. Egypt. International Journal of Remote Sensing Applications IJRSA, Volume 2, 24-29.

Asmar, H. M., Hereher, M. E., and Kafrawy, S. B. (2013). Surface Area Change Detection of the Burullus Lagoon, North of Nile Delta, Using a Remote Sensing Approach. Egypt Journal of Remote Sensing and Space Sciences, Volume 2, 24-29.

Ttia, G. M. (1992). Mineral and Geochemicals Studies On Subsurface Sediments, El - Burullus Lagoon North Nile Delta, Egypt. 
Bahrawy, A. E., Donia, N., and Farag, H. (2016). Nile- Eco- VWU Inventory and Assessment of Pilot Wetland Ecosystems and Identification of Services, Egypt.

Dewidar, K. M. (2002). Detection of land use/land cover changes for the northern part of the Nile delta, Egypt.

Donia, N., and Farag, H. (2012). Monitoring Burullus Lake Using Remote Sensing Techniques. Sixteenth International Water Technology Conference, Egypt.

El-Shinnawy, I. A. (2003). Reservoir Hydrologic Routing For Water Balance of Al-Burullus Wetland . Seventh International Water Technology Conference, Egypt.

Eszter Miókovics, J. B. (2014). Analysis of landscape change in the Nagyberek (Somogy, Hungary) with the DPSIR Framework. Natura Somogyiensis, Volume (24), 5-16.

Farag, H. A. (2011). Using Earth Observation (EO) Technique for Monitoring Water Quality in Lake Burullus, Nile Basin Water Science and Engineering Journal Volume 2, 24-30.

Frihy, O. E., and El-Sayed, M. K. (2013). Vulnerability risk assessment and Adaptation to Climate Change Induced SLR along the Mediterranean Coast of Egypt. Springer Science, Volume 18, 1215-1237.

GAFRD, (2015). Fish Statistics Year Book. Egypt.

Goll, B., N., Jianhua, L., and John, M. J. (2014). Analysis on the Causes of Deforestation and Forest Degradation in Liberia: Application of the DPSIR Framework. Research Journal of Agriculture and Forestry Sciences, Volume 2, 20-30.

Hegazy, I. R., and Kaloop, M. R. (2015). Monitoring Urban Growth and Land Use Change Detection with GIS and Remote Sensing Techniques in Daqahlia Governorate. The Egyptian Journal of Remote Sensing and Space Science, Volume 154, 951-958. 
Hossena, H., and Negm, A. (2016). Change Detection in the Water Bodies of Burullus Lake Using RS/GIS, Egypt. The Egyptian Journal of Remote Sensing and Space Science, Volume 3, 117-124.

IUCN, (2014). A guide to the Restoration Opportunities Assessment Methodology.

Karen P. J. Fortuin, C. S. (2011). The Value of Conceptual Models in Coping with Complexity and Interdisciplinarity in Environmental Sciences Education. BioScience Journal, Volume 61, 802-814.

Khedr, A.-H., and Lovett-Doust, J. (2000). Determinants of Floristic Diversity and Vegetation Composition on the Islands of Lake Burollos. Egypt, Applied Vegetation Science Journal, Volume 3, 147-156.

Kristensen, P. (2014). The DPSIR Framework. Nairobi, Kenya : European Environment Agency, Natura Somogyiensis Journal, Volume 24, 5-16.

Mashaly, I., El-Habashy, I., El-Halawany, E., and Omar, G. (2008). Habitats and Plant Communities in Nile Delta. Pakistan Journal of Biological Sciences, Volume 11, 2532-2544.

Mohamed, H., Zahran, M., Saavedra, O. C., and Negm, A. (2015). Assessement of Artificial Neural Network For Bathemetry Estimation Using High Resolution Satellite Imagery in Shallow Lakes: Case Study El Burullus Lake. Eighteenth International Water Technology Conference, Egypt.

Okbah, M. A., and Hussein, N. R. (2005). Impact of Enviromental Conditions on The Phytoplankton Structure In Mediterranean Sea Lagoon, Lake Burullus. Egypt: National Institute of Oceanography and Fisheries, Springer Journal, Volume 172, 129-150.

Patrício, J., Elliott, M., Mazik, K., Papadopoulou, K., and Smith, C. J. (2016). DPSIR - Two Decades of Trying to Develop A Unifying Framework for Marine Environmental Management. Frontiers Journal, Volume 3, 1-14. 
Samaan, A. A., Sheref, Z. M., and Ayouty, E. Y. (1989). Distibution of Chlorophyceae in Lake Burullus, Egypt.

Shaltout, K. H. (2017). Reed Products from Lake Burullus. Egypt, Springer Science Journal, Volume 10, 211-218.

Smeets, E., and Weterings, R. (1999). Environmental Indicators: Typology and Overview. Netherlands: European Environment Agency.

Statistics, C. A. (2011). Agricultural Statistics, Egypt.

UNEP (2015). Wetlands and Ecosystem Services. Convention of Biodiversty.

Zeiny, A. E., and Kafrawy, S. E. (2017). Assessement of Water Pollution Induced by Human Activities in Burullus Lake Using Landsat 8 Operational Land Imager and GIS. The Egyptian Journal of Remote Sensing and Space Science, Volume 20, 49-56.

Zingstra, H. L. (2013). Lake Burullus: Local Food Security and Biodiversity Under Pressure, Final Report. Centre for Development Innovation, Wageningen UR.

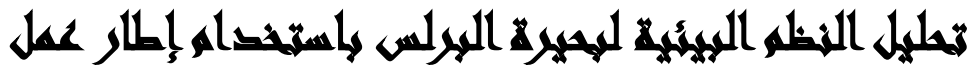

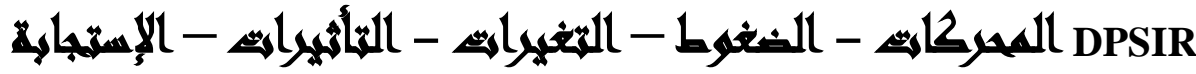

\section{[0]}

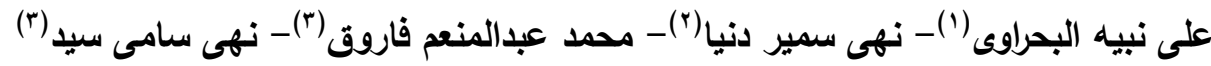

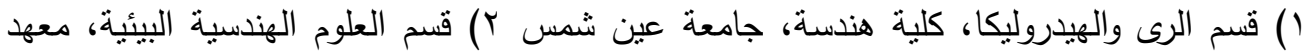
الدراسات والعلوم البيئية، جامعة عين شمس ب) قطاع الإدارة البيئية، وزارة شئون البئية البئة البئة

\section{مستطلي}

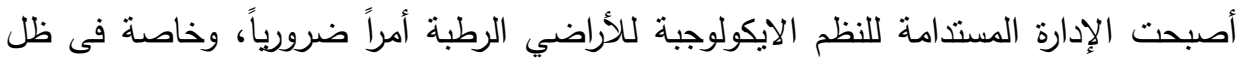

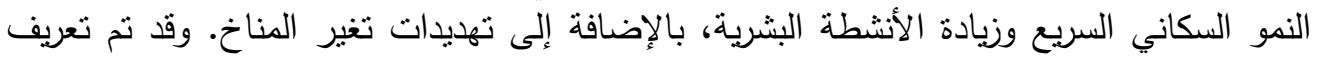

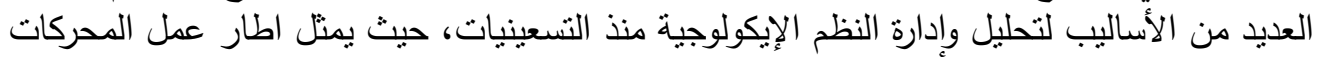

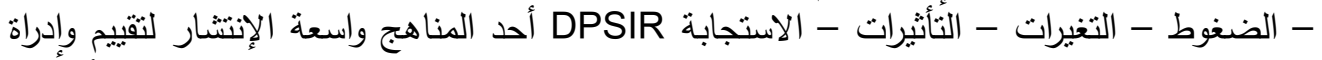
المشاكل البيئية. وقد طبقت هذه الدراسة إطار عمل DPSIR على بحيرة البرلس كنموذج للأراضي 
الرطبة الثمالية المصرية، من أجل تحليل نظامها الإيكولوجي من منظور مدى إمكانياتها لتقديم خدمات النظم الإيكولوجية ضمن الحالة الراهنة للتغيرات الناجمة عن الدوافع الإجتماعية والإقتصادية.

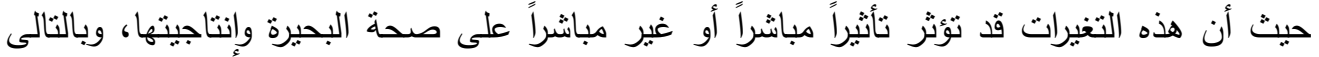

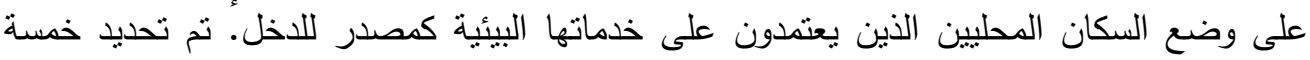

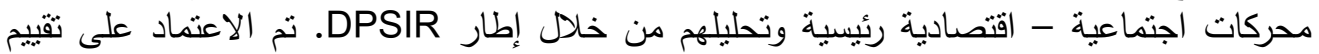
اطار عمل DPSIR فى تحديد بعض التوصيات لعدد من الأنشطة اللازمه لاعادة تأهيل البحيرة فى لـى

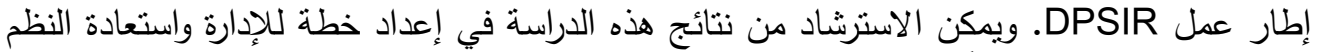

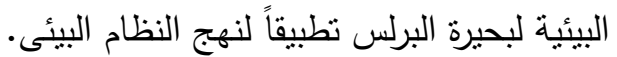

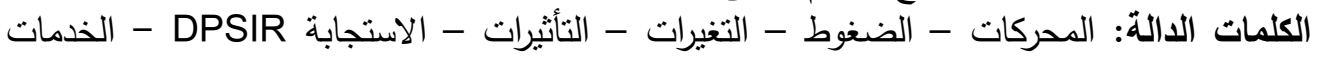

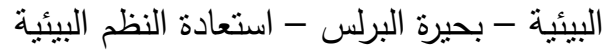

